\section{Assessing Shrub and Tree Encroachment in Alpine Pastures from Airborne Laser Scanning Data}

\author{
Christoph Giger \\ landplan AG Bern, Switzerland
}

GI_Forum 2019, Issue 2

Page: 73 - 80

Short Paper

Corresponding Author: christoph.giger@landplan.ch

DOI: 10.1553/giscience2019_02_s73

\begin{abstract}
The forest area in alpine regions is increasing. Agricultural land is abandoned; shrub and tree encroachment and reforestation are the consequences, with negative impacts on agriculture, biodiversity and tourism.

Assessing encroachment on agricultural land from Airborne Laser Scanning (ALS) data was tested in three study areas in Switzerland. The results of the data evaluation were compared with those for manually collected data from the interpretation of orthophotos. The evaluation indicated that when a higher point density was available, the detection rate for areas with shrub and tree encroachment was also higher. The workflow using the Vertical Complexity Index (VCI) turned out to be robust for both large areas and large datasets. The accuracy levels achieved in this study for the encroachment index may provide a solid basis for prioritizing certain areas for projects that aim to limit the process of reforestation.
\end{abstract}

\title{
Keywords:
}

airborne laser scanning ALS, secondary succession, shrub and tree encroachment, change detection

\section{Introduction}

As in all mountain areas in Europe, the total wooded area in Switzerland is increasing due to agricultural land abandonment. In the alpine pasture and meadow region in Switzerland, forest increases by 2,400 ha per year (Lauber et al., 2013, Brändli et al., 2014). This process is viewed negatively by various actors from the agriculture, nature conservation and tourism sectors. Experts and laypersons in Switzerland oppose reforestation strongly for a variety of reasons, especially in alpine pastures, which are an outstanding element of the cultural landscape of Switzerland (Baur et al., 2007, Brändli et al., 2014). Various projects aim to make such areas suitable for agriculture again. Adapted grazing, other livestock interventions, tree-felling or rooting out bushes help to keep the pasture land open in the long term. The canton of Valais, for example, has developed guidelines to assist communes (municipalities) in projects to work against the process of reforestation (Canton Valais, 2011). 
Observing the encroachment process can be done easily in the field over small areas, but monitoring large areas using remote sensing is challenging. Changes in land cover often concern just small patches, and discrimination between land uses can be difficult (Kolecka et al., 2015). In much research, the forest is in the foreground. Van Ewijk, Treitz and Scott (2011) used Light Detection and Ranging (LiDAR) indices to distinguish four stages of forest succession, but not to identify the reforestation stage. Multispectral or colour infrared aerial imagery in combination with Airborne Laser Scanning (ALS) data is widely used, with good results, for forest change detection by means of Object Based Image Analysis (OBIA) (Waser et al., 2008, Szostak, Wężyk and Tompalski, 2014, Blaschke, 2010).

In this paper, a practical approach for the detection of shrub and tree encroachment in agricultural land is presented, based on the author's Master's dissertation (Giger, 2018). The objectives of the thesis were (1) to verify whether it is possible or not to detect shrub and tree encroachment from ALS data using open source tools and standard available data; (2) to assess the minimum point density of ALS data required to obtain a reasonable detection rate.

\section{Data}

The study areas were selected based on recent land-use changes and availability of ALS data. Recent land-use changes were taken from the Swiss Land Use Statistics (Federal Statistical Office, 2014). Areas which changed land-use classes between 1992-97 and 2004-09 from 'agricultural area' to 'wooded area' were quantified and overlaid with the boundaries of summer pastures (these had not changed over the period in question). As most of the changes in the area statistics for the canton of Bern concerned Saxeten and Grandval, these two communes were selected for the study (Figure 1). The third test area, in Maienfeld, in the canton of Grisons (Figure 2), was chosen because of the comparatively high point density of the ALS dataset from the year 2002, as Maienfeld was probably scanned for test purposes using a density of more than 4 points $/ \mathrm{m} 2$. The extent of the area in Maienfeld corresponds exactly to an orthophoto tile from Swisstopo (the Swiss Federal Office of Topography).

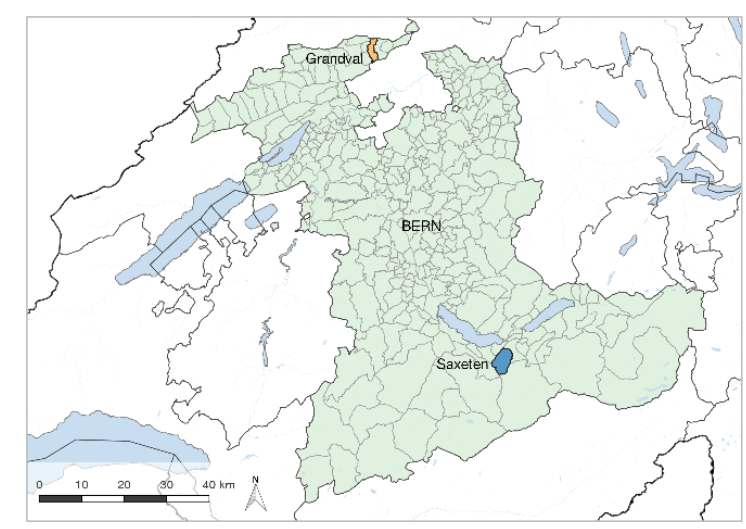

Figure 1: Communes Grandval and Saxeten in Bern canton 


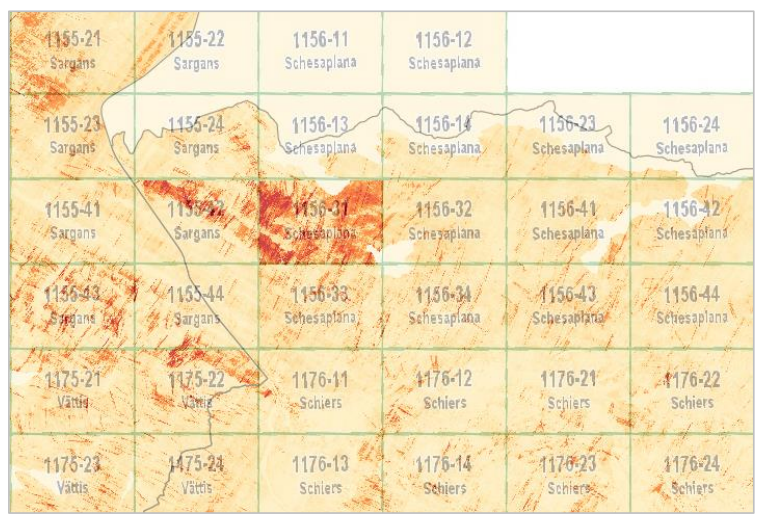

Figure 2: Study area Maienfeld in Grisons canton, recognizable by the dark red colour, which represents the high point density (tile number 1156-31).

In order to identify shrub and tree encroachment from ALS data, two datasets from different years are required. For study areas Saxeten and Grandval, ALS data from Swisstopo (Federal Office of Topography Swisstopo, 2019) collected in 2001was used as the first dataset. The second dataset was collected by the canton of Bern (Amt für Wald des Kantons Bern, 2013). For the Maienfeld study area, a dataset from 2002 provided by Swisstopo and one collected by the Swiss Federal Institute for Forest, Snow and Landscape Research (WSL) in 2015 were analysed (overview in Table 1).

To assess the accuracy of our results, orthophotos corresponding as closely as possible to the year of the ALS data collection were used. The orthophotos have a ground pixel size of 0.25 or $0.5 \mathrm{~m}$ and were provided by Swisstopo (Table 1).

Table 1: ALS data and orthophotos used in the three study areas

\begin{tabular}{|c|c|c|c|c|c|c|}
\hline \multirow{3}{*}{$\begin{array}{l}\text { year of ALS data } \\
\text { mean point } \\
\text { density } \\
\left(\text { points } / \mathrm{m}^{2}\right)\end{array}$} & \multicolumn{2}{|c|}{ Saxeten } & \multicolumn{2}{|c|}{ Grandval } & \multicolumn{2}{|c|}{ Maienfeld } \\
\hline & 2001 & 2012 & 2001 & 2011 & 2002 & 2015 \\
\hline & & & & & 4.2 & 21.7 \\
\hline $\begin{array}{l}\text { year of } \\
\text { orthophotos }\end{array}$ & 2004 & 2012 & 2004 & 2012 & 2002 & 2014 \\
\hline
\end{tabular}

\section{Methods}

The Vertical Complexity Index (VCI) based on the Shannon Index (Shannon, 1948) was used to identify shrub and tree structures in agricultural areas. The index can be used to determine the diversity or the uniformity of the height distribution of ALS points. 
In order to calculate the VCI, a normalised ALS point cloud was divided into a number of height bins (HB). The number of LiDAR returns per height bin as a proportion of the total number of LiDAR returns was used to define $p_{i}$.

$$
V C I=\left(-\sum_{i=1}^{H B}\left[\left(p_{i}\right) \cdot \ln \left(p_{i}\right)\right]\right) / \ln (H B)
$$

A VCI value close to 1 indicates that most height bins have equal numbers of points. As the distribution of points per height bin becomes more uneven, VCI decreases (van Ewijk et al., 2011). Van Ewijk et al. used the VCI to differentiate the succession stages of forest stands from ALS data, but not to differentiate between bare ground or pastures and the initiation stage. For the stem exclusion stage, the same authors measured a mean VCI of 0.63 ; for the understorey re-initiation stage, a mean VCI of 0.75 , and for the old growth stage, a mean VCI of 0.80 . The analysis of the results obtained from the encroachment indicator calculation showed that for shrub and tree encroachment a VCI of less than 0.63 could be expected. Therefore, a threshold of 0.61 was chosen in order to distinguish between areas with encroachment and an understorey re-initiation stage. In addition, the maximum $Z$-value was calculated and included in order to reduce unidentified individual trees. Grid cells with a maximum Z-value of more than $3.5 \mathrm{~m}$ were excluded. The spatial resolution was set at $3 \times 3 \mathrm{~m}$, as a compromise between accuracy and computational cost. The differences between the resulting VCIs from the old (t1) and the new (t2) ALS data show potential areas of encroachment (Figure 3).
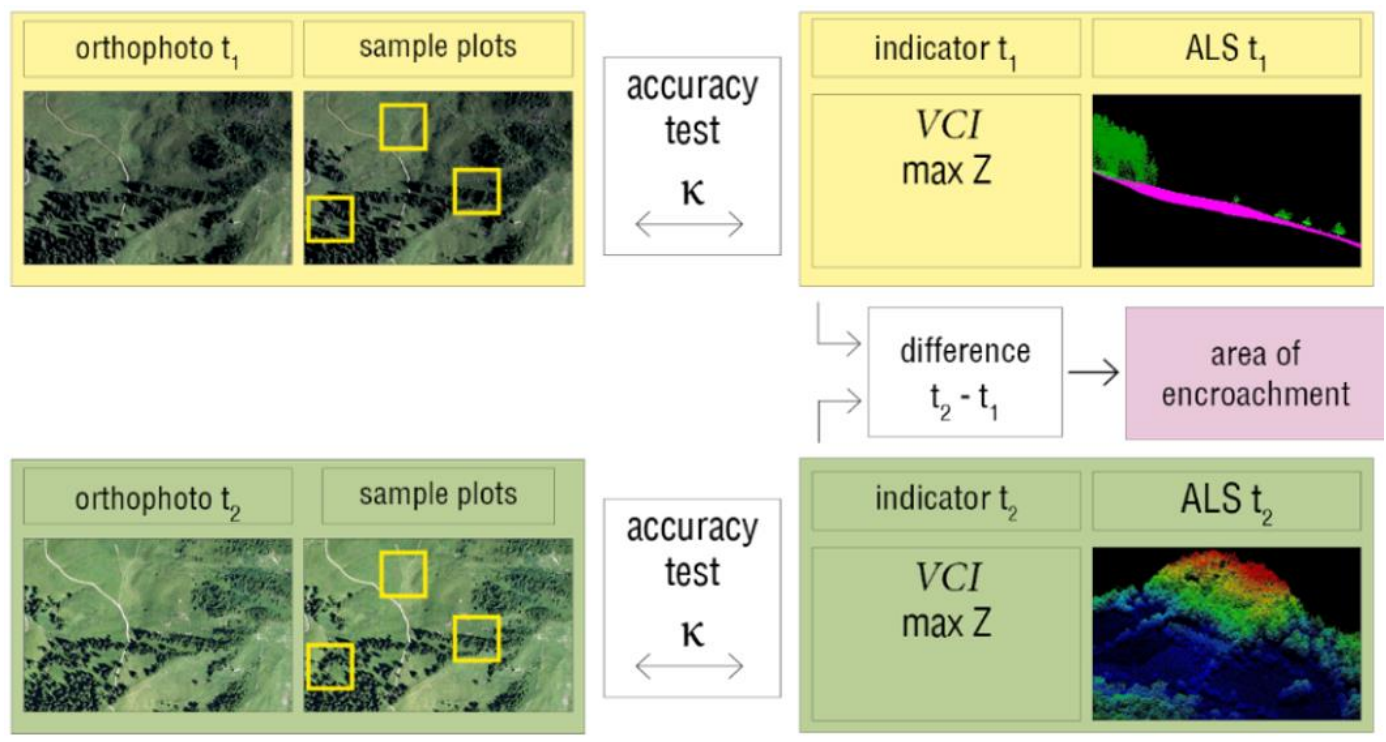

Figure 3: Workflow of data analysis: orthophoto interpretation on the left, $\mathrm{VCl}$ calculation on the right

Figure 3 shows the workflow for analysing the old and new orthophotos and the ALS data, which was carried out for each study area. The accuracy of the VCI calculated combined with 
a maximum Z-value is verified by comparing it with manually digitized information from orthophotos. For each study area, 450 sample plots were classified as plots with shrub and trees, or plots without. The area of shrub and tree encroachment was obtained from the difference between the indicators calculated from old and new ALS data.

The raw data were filtered and normalized with PDAL (Point Data Abstraction Library, Version 1.5); VCI and the maximum Z-value were calculated using the lidR package (version 1.2.0) in R; the results were stored in a PostgreSQL database. There, the POSTGIS extension was used to combine the VCI and the maximum Z-value, to calculate the changes between the old and the new datasets, and from these to determine the areas with an increase in shrub and tree structures (Figure 4).



raw data LAZ files

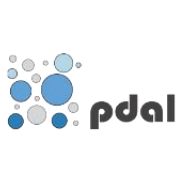

filter

remove noise

normalization

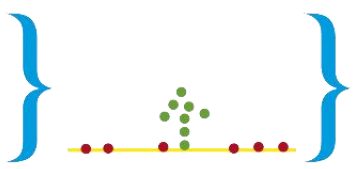

corrected data

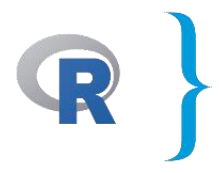

lidR

calculation VCl

and max z-value

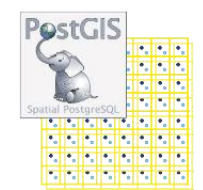

change detection

$t_{1}-->t_{2}$

Figure 4: Workflow for processing ALS data and extracting areas of encroachment

To assess the accuracy of the ALS data interpretation, 450 plots $(12 \times 12 \mathrm{~m})$ per study area were evaluated using orthophotos from the year in which the ALS data was collected (+/- 3 years). The plots were categorized as plots with shrubs and trees, and plots without. Figure 5 shows a sample plot classified as a plot with shrubs and trees, Figure 6 a plot without shrubs and trees, and Figure 7 a plot which is not classified due to shadows. Forested areas or areas with large trees were assigned to 'unclassified', as were plots affected by shadow (e.g. of large trees or the topography). The threshold for the category 'shrubs and trees' is $25 \%$ coverage of the plot area.

For comparison with the orthophoto interpretation, the grid cells $(3 \times 3 \mathrm{~m})$ classified as 'shrubs and trees' based on ALS data were aggregated to the size of a sample plot (12 x $12 \mathrm{~m})$. If at least 4 cells in a plot were classified as 'shrub and trees', the plot as a whole was assigned to the category 'shrubs and trees'. 


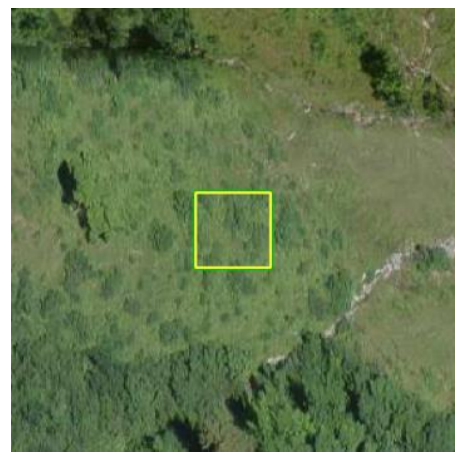

Figure 5: control area, classified as shrubs and trees

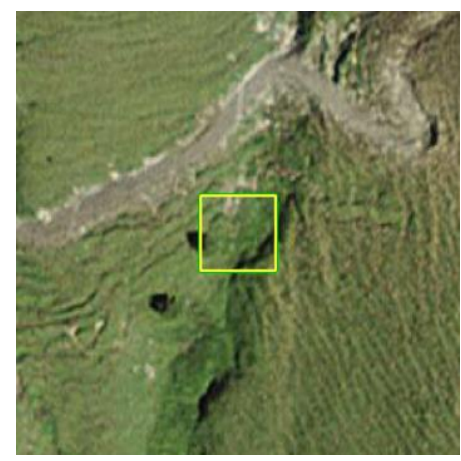

Figure 6: control area without shrubs and trees, classified as other

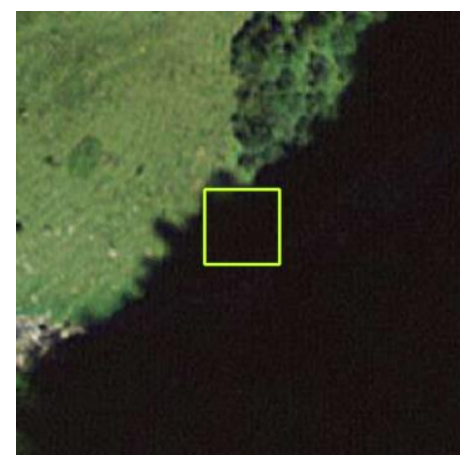

Figure 7: due to shadows, assigned to unclassified

\section{Results}

Table 2 shows the results of the orthophoto interpretation for each classification category. In all areas, the percentage of 'shrubs and trees' increased between the old and the new datasets. While 'unclassified' plots decreased in the Saxeten and Maienfeld study areas, for Grandval there was an increase.

Table 2: Comparison of orthophoto interpretation

\begin{tabular}{l|ll|ll|ll} 
& Saxeten & & Grandval & & Maienfeld \\
year of orthophoto & $2004\left(t_{1}\right)$ & $2012\left(t_{2}\right)$ & $2004\left(t_{1}\right)$ & $2012\left(t_{2}\right)$ & $2002\left(t_{1}\right)$ & $2014\left(t_{2}\right)$ \\
shrubs and trees [\%] & 17.1 & 20.7 & 1.8 & 7.3 & 6.7 & 12 \\
other [\%] & 70.8 & 68.4 & 85.8 & 80.9 & 91.6 & 87.3 \\
unclassified [\%] & 12.1 & 11 & 8.6 & 11.8 & 1.8 & 0.7 \\
plots classified [n] & 400 & 405 & 394 & 397 & 442 & 447
\end{tabular}

Data derived from orthophoto interpretation were used as reference data for the accuracy assessment. The number of sample plots correctly classified by the ALS data calculation is of primary interest and represented by the producer's accuracy (PA) for the category 'shrubs and trees'.

As shown in Table 3, the PA for category 'other' ranges from 83 to $98 \%$, for both the old and the new ALS datasets. For the category 'shrubs and tree', we obtained accuracies between 34 and $74 \%$ for the old dataset and between 57 and $79 \%$ for the new dataset. 
Table 3: Comparison of Producer's accuracy (PA) and User's accuracy (UA) in the three study areas

\begin{tabular}{|c|c|c|c|c|c|c|c|c|c|c|}
\hline \multirow[t]{2}{*}{$\begin{array}{l}\text { Study } \\
\text { area }\end{array}$} & \multirow[t]{2}{*}{$\begin{array}{l}\text { Point } \\
\text { density ALS } \\
\text { data }\left[\mathrm{p} / \mathrm{m}^{2}\right]\end{array}$} & \multicolumn{2}{|c|}{$\begin{array}{l}\text { Old data } \\
\left(t_{1}\right) \text {, } \\
\text { category } \\
\text { other } \\
{[\%]}\end{array}$} & \multicolumn{2}{|c|}{$\begin{array}{l}\text { Old data } \\
\left(t_{1}\right) \text {, } \\
\text { category } \\
\text { shrubs and } \\
\text { trees [\%] }\end{array}$} & \multirow[t]{2}{*}{$\begin{array}{l}\text { Point density } \\
\text { ALS data } \\
{\left[\mathrm{p} / \mathrm{m}^{2}\right]}\end{array}$} & \multicolumn{2}{|c|}{$\begin{array}{l}\text { New data } \\
\left(t_{2}\right) \text {, } \\
\text { category } \\
\text { other [\%] }\end{array}$} & \multicolumn{2}{|c|}{$\begin{array}{l}\text { New data } \\
\left(t_{2}\right), \\
\text { category } \\
\text { shrubs and } \\
\text { trees [\%] }\end{array}$} \\
\hline & & PA & UA & PA & UA & & $\mathrm{PA}$ & UA & PA & UA \\
\hline Saxeten & 1.5 & 83 & 93 & 34 & 25 & 18.9 & 90 & 86 & 58 & 67 \\
\hline Grandval & 1.2 & 97 & 98 & 43 & 35 & 9.8 & 98 & 95 & 57 & 79 \\
\hline Maienfeld & 4.2 & 96 & 99 & 74 & 47 & 21.7 & 94 & 98 & 79 & 57 \\
\hline
\end{tabular}

\section{Conclusion}

The study shows that it is possible to quantify shrub and tree encroachment in alpine pastures in Switzerland using ALS data with medium to high point density. By extending the VCI with a maximum Z-value, a reliable shrub and tree encroachment indicator for alpine regions was calculated. In Maienfeld, for both the old and new ALS datasets, data with middle to high point density was available. This good data quality led to the following results: for the category 'shrubs and trees', a producer's accuracy of 74\% (ALS data 2002, 4.2 points $/ \mathrm{m} 2$ ) and $79 \%$ (ALS data 2015, 21.7 points/m2) was achieved.

While point density has an influence on the accuracy, it is not possible to derive from the results the minimum point density of ALS data required to obtain a reasonable detection rate. Study-area-specific difficulties and various sources of error may have more impact than the point density. The two lowest producer's accuracies were obtained from ALS data with low point density - of 1.2 and 1.5 points $/ \mathrm{m} 2$.

The study shows that the VCI, implemented in the R-package lidR, in combination with the maximum Z-value is suitable for the workflow presented here. If new ALS data become available in the future, it will be possible to carry out the analysis to identify areas with shrubs and tree encroachment. A larger-scale analysis could serve as the basis for funding decisions for projects that limit the process of reforestation in Switzerland. 


\section{References}

Amt für Wald des Kantons Bern. (2013). LIDAR-Daten Kanton Bern. Retrieved from http://files.be.ch/bve/agi/geoportal/geo/lpi/LDOM50CM_2012_01_LANG_DE.pdf

Baur, P., Müller, P. \& Herzog, F. (2007). Alpweiden im Wandel. Agrarforschung, 14, 254-259.

Blaschke, T. (2010). Object based image analysis for remote sensing. ISPRS Journal of Photogrammetry and Remote Sensing, 65, 2-16.

Brändli, U., Cioldi, F., Fischer, C., Herold-Bonardi, A., Keller, H. \& Meile, R. (2014). Viertes Schweizerisches Landesforstinventar-Ergebnistabellen und Karten im Internet zum LFI 2009-2013 (LFI4b). Eidgenössische Forschungsanstalt für Wald, Schnee und Landschaft WSL, Birmensdorf.

Canton Valais. (2011). Leitfaden zum Vorgehen für Gemeinden mit Waldeinwuchs im Wallis. Retrieved from https://www.vs.ch/web/sfcep/extension-des-forets

Federal Office of Topography Swisstopo. (2019). LiDAR Data Aquistion. Retrieved from

https://www.swisstopo.admin.ch/en/knowledge-facts/geoinformation/lidar-data.html

Federal Statistical Office FSO. (2014). Arealstatistik Bodenbedeckung nach Nomenklatur 2004 -

Metainformation zu Geodaten. Retrieved from

https://www.bfs.admin.ch/bfs/de/home/statistiken/raum-

umwelt/nomenklaturen/arealstatistik/nolc2004.assetdetail.313706.html

Giger, C. (2018). Assessing Shrub and Tree Encroachment in Alpine Pastures from Airborne Laser Scanning Data. http://unigis.sbg.ac.at/files/Mastertheses/Full/104172.pdf

Kolecka, N., Kozak, J., Kaim, D., Dobosz, M., Ginzler, C. \& Psomas, A. (2015). Mapping secondary forest succession on abandoned agricultural land with LiDAR point clouds and terrestrial photography. Remote Sensing, 7, 8300-8322.

Lauber, S., Herzog, F., Seidl, I., Böni, R., Bürgi, M., Gmür, P., Hofer, G., Mann, S., Raaflaub,

M. \& Schick, M. (2013). Zukunft der Schweizer Alpwirtschaft. Fakten, Analysen und

Denkanstösse aus dem Forschungsprogramm AlpFUTUR. Eidgenössische Forschungsanstalt für

Wald, Schnee und Landschaft WSL, Birmensdorf.

Shannon, C. E. (1948). The mathematical theory of communication. Bell System Technical Journal, 27, 379423 and 623-656.

Szostak, M., Wężyk, P., \& Tompalski, P. (2014). Aerial orthophoto and airborne laser scanning as monitoring tools for land cover dynamics: A case study from the Milicz Forest District (Poland). Pure and Applied Geophysic, 171(6), 857-866. doi:10.1007/s00024-013-0668-8

Van Ewijk, K. Y., Treitz, P. M. \& Scott, N. A. (2011). Characterizing forest succession in Central Ontario using LiDAR-derived indices. Photogrammetric Engineering \& Remote Sensing, 77, 261-269.

Waser, L.T., Baltsavias, E., Ecker K., Eisenbeiss, H., Feldmeyer-Christe, E., Ginzler, C., Küchler, M., Zhang, L. (2008). Assessing changes of forest area and shrub encroachment in a mire ecosystem using digital surface models and CIR aerial images. Remote Sensing of Environment, 112 (5), 1956-1968. 